\title{
MENIMBANG HERMENEUTIKA DALAM STUDI HUKUM ISLAM
}

\author{
H. Iman Fadhilah, S.HI., M.SI \\ Kajur Hukum Ekonomi Syari'ah, Universitas Wahid Hasyim Semarang \\ Pengurus PWNU Jawa Tengah \\ imanfadhilah2@gmail.com
}

\begin{abstract}
Abstrak
Selama ini metode yang dipakai oleh para ulama dalam memahami dan menjelaskan maksud ayat-ayat Al-Qur'an adalah metode tafsir, baik yang bi al-ma'tsûr maupun yang bi ar-ra'yi. Tetapi beberapa tahun belakangan ini, mulai ditawarkan metode lain yang diklaim lebih sesuai untuk menjawab tantangan zaman sekarang ini, yaitu metode hermeneutika yang berasal dari tradisi Barat dalam memahami Alkitab. Ada yang hanya menggunakan metode hermeneutika sekadar sebagai pelengkap atau pendamping metode tafsir yang sudah dikenal selama ini, tetapi ada juga yang bersemangat ingin mengganti metode tafsir dengan hermeneutika. Makalah ini mencoba menggambarkan secara ringkas kedua metode tersebut dengan sebuah sikap, jika memang ada yang baik dari hermeneutika dan dapat membantu kita memahami Al-Qur'an dan as-Sunnah dengan lebih baik, kenapa tidak kita ambil. Sebaliknya kita juga tidak akan mengalami kesulitan apa-apa meninggalkannya jika tenyata tidak ada manfaatnya. Sikap kritis dan selektif itulah yang harus selalu dipelihara.
\end{abstract}

Kata kunci: Hukum Islam, Hermeneutika, studi Islam

\begin{abstract}
All this time, the method used by Ulama' for understanding and explaining of AlQur'an meaning is an interpretation method, both ofbi al-ma'tsûrand bi ar-ra'yi.In recent years, there is another method that is claimed as suitable for answering today's challenges, namely hermeneutic method, is from western tradition which hermeneutic method is applied in understanding the Bible.Some persons use only hermeneutic methods simply as a complement or companion of interpretationmethod that has been known all this time, however there are also eager to change from the interpretation method to hermeneutics.This paper tries to briefly describe both methods with an attitude, if there is something good from hermeneutic and can help us understand the Qur'an and as-Sunnah better, why not we take it. In contrast, we will not have any trouble when leaving if the hermeneutic does not have benefit. This critical and selective attitude must always be maintained.
\end{abstract}

\section{Keywords: Islamic law, Hermeneutic, Islamic studies.}




\section{Pendahuluan}

Secara etimologi tafsir berarti keterangan dan penjelasan (al-idhâh wa attabyîn). Dan secara terminologi tafsir adalah keterangan dan penjelasan tentang arti dan maksud ayat-ayat Al-Qur'an sebatas kemampuan manusia. ${ }^{1}$ Dalam menafsirkan Al-Qur'an, di samping dibatasi oleh kemampuan masing-masing sebagai manusia, para mufassir juga dipengaruhi oleh latar belakang pendidikan, sosial budaya yang berbeda-beda, sehingga metode dan corak penafsiran mereka juga berbeda-beda.

Sejauh ini, dari segi metode dikenal ada dua aliran penafsiran, yaitu at-tafsîrbi al- ma'tsûr dan at-tafsîrbi-ar-ra'yi. Dan dari segi corak lebih beragam, ada yang bercorak sastra bahasa, fiqh, teologi, filsafat, tasawuf, ilmiyah dan corak sastra budaya kemasyarakatan.

Usaha menafsirkan Al-Qur'an sudah dimulai semenjak zaman para sahabat Nabi sendiri. 'Ali ibn Abi Thâlib, 'Abdullah ibn 'Abbâs, 'Abdullah Ibn Mas'ûd dan Ubayya ibn $\mathrm{Ka}$ 'ab adalah di antara para sahabat yang terkenal banyak menafsirkan ayat-ayat Al-Qur'an dibandingkan dengan sahabat-sahabat yang lain. ${ }^{2}$

Menafsirkan ayat-ayat Al-Qur'an para sahabat pertama-tama menelitinya dalam Al-Qur'an sendiri, karena ayat-ayat Al-Qur'an satu sama lain saling menafsirkan; Kedua, merujuk kepada penafsiran Nabi Muhammad SAW, sesuai dengan fungsi beliau sebagai mubayyin terhadap ayat-ayat Al-Qur'an; Ketiga, apabila mereka tidak menemukan keterangan tentang ayat tertentu dalam Al-Qur'an dan tidak sempat menanyakannya kepada Rasulullah SAW, para sahabat berijtihad dengan bantuan pengetahuan bahasa Arab, pengenalan terhadap tradisi Arab dan keadaan orang-orang Yahudi dan Nasrani di Arabia pada waktu ayat turun atau latar belakang ayat tersebut diturunkan, dan dengan menggunakan kekuatan penalaran mereka sendiri. Baru yang terakhir, sebagian sahabat ada pula menanyakan beberapa masalah, khususnya sejarah Nabi-Nabi atau kisah-kisah yang tercantum dalam Al-Qur'an

\footnotetext{
${ }^{1}$ Muhammad Husain adz-Dzahabi, at-Tafsîr wa al-Mufassirûn (Kairo: Dar al-Kutub alHadîtsah, 1976), jilid I, hlm. 13-15.

${ }^{2}$ Jalâl ad-Dîn 'Abd ar-Rahmân as-Suyûthi, al-Itqân fí 'Ulûm Al-Qur'an (Beirut: Dar al-Fikr, t.t.), hlm. 187.
} 
kepada tokoh-tokoh Ahlul Kitab yang telah memeluk agama Islam, seperti 'Abdullah ibn Salâm, Ka'ab al-Ahbâr dan lain-lain. ${ }^{3}$

Tafsir pada masa sahabat ini belum merupakan ilmu sendiri, masih merupakan bagian dari riwayat-riwayat hadits yang berserakan, belum sistematis seperti tafsir yang kita kenal sekarang. Di samping belum sistematis, pada masa sahabat ini pun Al-Qur'an belum ditafsirkan secara keseluruhan, dan pembahasannya pun belum luas dan mendalam. ${ }^{4}$

Sesudah periode sahabat, datanglah generasi berikutnya (tabi'in) meneruskan usaha yang telah dirintis oleh para sahabat. Di samping menafsirkan Al-Qur'an dengan Al-Qur'an dan Hadits Nabi, mereka juga merujuk kepada penafsiran para sahabat dan sebagian juga tidak lupa mengutip dari Ahlul Kitab. Setelah itu baru mereka mengembangkan penafsiran sendiri berdasarkan ijtihad. Pada masa tabi'in ini, tafsir masih merupakan bagian dari hadits, tapi sudah mengelompok menurut kota masing-masing. 5

Tabi'in Makkah seperti Mujâhid ibn Jâbir, 'Athâ' ibn Abi Ribâh dan 'Ikrimah Maulâ Ibn 'Abbâs meriwayatkan dari Ibn 'Abbâs. Tabi'in Madinah seperti Muhammad ibn Ka'ab al-Qurazhi, Abû' al-'Aliyah ar-Riyâhi dan Zaid ibn Aslam meriwayatkan dari Ubayya ibn Ka'ab. Tabi'in 'Iraq seerti al-Hasan al-Bashri, Masrûq ibn al-Ajdâ' dan Qatâdah ibn Di'âmah meriwayatkan dari 'Abdullah Ibn Mas'ûd. Adz-Dzahabi menyebut madrasah tersebut dengan Madrasah Makkah, Madrasah Madinah dan Madrasah 'Iraq. ${ }^{6}$

Sesudah masa sahabat dan tabi'in datanglah masa kodifikasi (tadwîn) hadits di mana riwayat-riwayat berisi tafsir dikelompokkan menjadi satu bab sendiri, walaupun tetap belum sistematis seperti susunan Al-Qur'an. Dalam perkembangan selanjutnya tafsir dipisahkan dari kandungan kitab hadits dan menjadi kitab sendiri. Para ulama seperti Ibnu Mâjah (w. 273 H), Ibnu Jarîr at-Thabari (w. 310 H), Abû Bakar ibn AlMunzir an-Naisabûri (w. 318 H) dan lain-lain mengumpulkan riwayat-riwayat yang berisi tafsir dari Nabi, sahabat dan tabi'in dalam kitab sendiri. Riwayat-riwayat yang

\footnotetext{
${ }^{3}$ Yunahar Ilyas, Feminsme dalam Kajian Tafsir Al-Qur'an Klasik dan Kontemporer (Yogyakarta: Pustaka Pelajar, 1997), hlm. 15-17.

${ }^{4}$ Ibid., hlm. 17-18.

${ }^{5}$ Muhammad Husain adz-Dzahabi, at-Tafsîr wa al-Mufassirûn, I:99 dan 130.

${ }^{6}$ Ibid, I:101, $1 \overline{14}$ dan 118.
} 
dikumpulkan itu sudah mencakup keseluruhan ayat-ayat Al-Qur'an dan disusun sesuai dengan sistematika mushhaf. Metode yang dirintis Ibnu Jarîr dan mufassir lain pada masa awal pembukuan tafsir inilah yang kemudian di kenal dengan metode at-tafsîrbi al-ma'tsûr. ${ }^{7}$

Ringkasnya, metode at-tafsîrbi al-ma'tsûr adalahmenafsirkan Al-Qur'an dengan Al-Qur'an, Al-Qur'an dengan Sunnah Nabi dan Al-Qur'an dengan pendapat atau penafsiran para sahabat Nabi. dan tabi' in ${ }^{8}$. Dinamai dengan bi al-ma'tsûr (dari kata atsar yang berarti sunnah, hadits, jejak, peninggalan) ${ }^{9}$.

Beberapa kitab-kitab tafsir yang menggunakan metode at-tafsîrbi al-ma'tsûr ini adalah: (1) Muhammad Ibn Jarîr ath-Thabari (w. 310 H), Jâmi’ al-Bayân fi Tafsîr Al-Qur'an; (2) Abu al-Fadâ' Ismâ'l ibn 'Amr ibn Katsîr (w. 774 H), Tafsîr Al-Qur'an al- 'Azhîm; (3) Jalâl ad-Dîn as-Suyûthi (w. 849 H), Ad-Durr al-Mantsûr fî at-Tafsîr alMa'tsûr. ${ }^{10}$

Sementara itu, setelah ilmu pengetahuan tumbuh dan berkembang pesat pada masa Daulah'Abbasiyah, para mufassir tidak puas hanya dengan metode bi alma'tsûr, karena perubahan dan perkembanganzaman menghendaki pengembangan metode tafsir dengan memperluas dan memperbesar peran ra'yu atau ijtihad dibandingkan dengan penggunaannya pada metode bi al- ma'tsûr. Tafsir dengan metode ini kemudian dikenal dengan at-tafsîrbi-ar-ra'yi.

Metode at-tafsîrbi-ar-ra'yi seorang mufassir menafsirkan ayat-ayat Al-Qur'an dengan menggunakan kemampuan ijtihad atau pemikiran tanpa meninggalkan tafsir Al-Qur'an dengan Al-Qur'an atau dengan hadits dan tidak pula meninggalkan sama sekali penafsiran para sahabat dan tabi'in. Metode ini mengembangkan penafsiran dengan bantuan bermacam-macam ilmu pengetahuan seperti ilmu bahasa Arab, ilmu qira'ah, ilmu-ilmu Al-Qur'an, ilmu hadits, ushul fiqh, ilmu sejarah, dan lain-lain sebagainya. Dinamai dengan at-tafsîrbi- ar-ra'yi karena yang dominan memang penalaran atau ijtihad mufassir itu sendiri.

${ }^{7}$ Ibid, I: 141-142.

${ }^{8}$ Mannâ' al-Qaththâan, Mabâhits fì 'Ulûm Al-Qur'an (Riyâdh: Muassasah ar-Risâlah, 1976), hlm. 347.

${ }^{9}$ Ahmad Warson Munawwir, Kamus al-Munawwir, Arab-Indonesia (Yogyakarta: Pondok Pesantren al-Munawwir, 1984), hlm. 7.

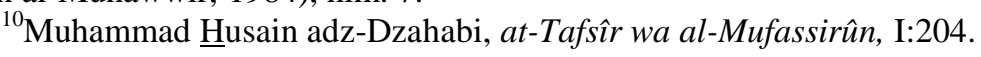


Beberapa kitab-kitab at-tafsîrbi- ar-ra'yi adalah: (1) Abû al-Qâsim Jârullah Mahmûd ibn 'Umar az-Zamakhsyari al-Khawârizmi (w. 538 H), Al-Kasysyâf 'an Haqâiz at-Tanzîl wa 'Uyûn al-Aqâwil fi Wujûh at-Ta'wîl'; (2) Abû'Abdillah Muhammad ibn 'Umar ar-Râzi (w. 639 H), Mafâtih al-Ghaib; (3) Abû al-Fadhl Syihâb ad-Dîn as-Sayyid Mahmûd al-Alûsi al-Baghdâdi (w. 1270 H), Rûh al-Ma'âni fì Tafsîr Al-Qur'an al- 'Azhîm wa as-Sab'i al-Matsâni. ${ }^{11}$

\section{Pembahasan}

\section{A. Hermeneutika}

Secara etimologis kata hermeneutika (Indonesia) atau hermeneutic (Inggris) berasal dari bahasa Yunani, hermeneuein yang berarti menafsirkan. Istilah ini diambilkan dari nama Hermes, yaitu nama seseorang dalam mitologi Yunani yang bertugas menyampaikan dan menafsirkan pesan-pesan dari dewa di Gunung Olympus ke dalam bahasa yang dapat dimengerti oleh umat manusia. Mengacu kepada nama Hermes itulah, kata kerja hermeneuein dipahami sebagai menafsirkan suatu pesan "dari dunia lain" kepada orang atau masyarakat yang berhadapan dengan pesan itu dalam konteks sosial historisnya sendiri. ${ }^{12}$

Secara terminologis, hermeneutika adalah ilmu dan teori tentang penafsiran yang bertujuan menjelaskan teks mulai dari ciri-cirinya, baik objektif (arti gramatikal kata-kata dan variasi-variasi historisnya), maupun subjektif (maksud pengarang). ${ }^{13}$

Kata hermeneutika menunjukkan seluruh wilayah berlangsungnya kegiatan hermeneuein yang paling tidak terdiri dari tiga unsur utamanya: (1) Adanya tanda, pesan, berita yang seringkali berbentuk teks; (2) Harus ada sekelompok penerima yang bertanya-tanya atau merasa asing terhadap pesan atau teks itu; dan (3) Adanya pengantara yang dekat dengan kedua belah pihak. ${ }^{14}$

\footnotetext{
${ }^{11}$ Ibid., I:289.

12 FX. Mudji Sutrisno dan F. Budi Hardiman (ed), Para Filsuf Penentu Gerak Zaman (Yogyakarta: Kanisius, 1994), hlm. 74, dan E. Sumaryono, Hermeneutik Sebuah Metode Filsafat (Yogyakarta: Kanisisus, 1993), hlm. 23.

${ }^{13}$ Lihat Lorens Bagus, Kamus Filasafat (Jakarta: Gramedia, 1996), hlm. 283.

${ }^{14}$ FX. Mudji Sutrisno dan F. Budi Hardiman, Para Filsuf...hlm. 74.
} 
Hermeneutika terutama berurusan dengan teks-teks, lebih khusus lagi teksteks masa lampau. Problematika teks baru muncul tatkala kita membaca teks yang berasal dari zaman dahulu. Kontak pembaca dengan pengarangnya terputus oleh sebuah rentang waktu yang panjang, sehingga kata-kata, kalimat-kalimat dan terminologi-terminologi khusus dalam teks itu sulit dipahami atau bahkan bisa disalahpahami. Pembaca berusaha menangkap makna sebagaimana yang dimaksudkan oeh pengarangnya. Pembaca berhadapan dengan problematika otentitas makna teks. Problematika teks di atas tidak akan terjadi apabila pembaca dan pengarang hidup dalam zaman yang sama, sekalipun tidak berjumpa secara langsung. Ketidakjelasan makna teks dapat diatasi dengan pemahaman terhadap kata-kata, kalimat-kalimat dan terminologi khusus yang memang sudah dikenal pada zaman itu. Apa yang tertulis dalam teks itu dapat ditangkap oleh pembaca secara kurang lebih lurus dari makna yang dimaksud pengarangnya. ${ }^{15}$

Hermeneutika sebagai sebuah metode untuk memahami pesan atau teks sudah dikenal dan digunakan sepanjang sejarah dalam meneliti teks-teks kuno yang otoritatif seperti kitab suci, atau untuk meneliti dokumen sejarah dan karya sastra. Corak dan bentuk penafsiran terhadap teks sepanjang sejarahnya ditentukan oleh pemahaman penafsir terhadap teks itu sendiri. Dalam dunia Kristen misalnya, dalam abad-abad pertama masehi sudah muncul dua corak penafsiran terhadap teks kitab suci mereka. Mazhab Antiokhia dikenal dengan penasiran harfiah, sedangkan mazhab Aleksandria dikenal dengan penafsiran secara simbolis atau alegoris. Bahkan dalam zaman reformasi, agama Kristen terpecah karena perbedaan prinsip-prinsip hermeneutik. Katolik berpegang pada prinsip tradisi, sementara Protestan memegang prinsip sola scriptura (hanya kitab suci). ${ }^{16}$

Refleksi kritis mengenai hermeneutika dirintis oleh Friedric Schleiermacher (1768-1834). Menurut filsuf Jerman ini, ada dua tugas hermeneutik yang pada hakikatnya identik satu sama lain, yaitu interpretasi gramatikal dan interpretasi psikologis. Untuk memahami sebuah teks, seorang interpretator harus

\footnotetext{
${ }^{15}$ F. Budi Hardiman, “Hermeneutik itu Apa?”, dalam Majalah Basis, no. 40, th. 1991, hlm. 2.

${ }^{16}$ Ibid., hlm. 8 .
} 
memahami keduanya sama baiknya, yaitu bahasa dan jiwa penulis teks tersebut. Untuk itu Schleiermacher menawarkan dua macam rekonstruksi, yaitu rekonstruksi obyektif-historis dan rekonstruksi subyektif-historis. Dengan rekonstruksi pertama ia bermaksud membahas sebuah pernyataan dalam hubungan dengan bahasa sebagai keseluruhan, dan dengan rekonstruksi kedua ia bermaksud membahas asal mulanya sebuah pernyataan masuk dalam pikiran seseorang. Schleiermacher sendiri menyatakan bahwa tugas hermeneutik adalah memahami teks sebaik atau lebih baik daripada pengarangnya sendiri, dan mahami pengarang teks lebih baik daripada mahami dirinya sendiri. ${ }^{17}$

Filsuf lain yang mengembangkan gagasan filosofis mengenai hermeneutik adalah Wilhem Dilthey (1833-1911). Filsuf yang juga berasal dari Jerman ini berpendapat, mengatasi psikologisme Schleiermacher, bahwa peristiwa-peristiwa yang termuat dalam teks-teks kuno itu harus dipahami sebagai suatu ekspresi kehidupan sejarah, maka yang direproduksi bukanlah keadaan-keadaan psikhis pengarang, melainkan makna peristiwa-peristiwa sejarah itu. Meskipun demikian, Dilthey tetap berada pada garis yang sama dengan Schleiermacher, yaitu sama-sama memahami hermeneutika sebagai penafsiran reproduktif. ${ }^{18}$

Berbeda dengan Schleimacher dan Dilthey, Hands Gadamer ( lahir tahun 1900), melihat bahwa kesenjangan waktu antara pembaca dan pengarang tidak harus diatasi seolah-olah sebagai suatu yang negatif, malainkan justru harus dipikirkan sebagai perjumpaan horison-horison pemahaman. Pembaca memperkaya horison pemahamannya dengan membandingkannya dengan horison pengarang. Oleh karena itu, bagi Gadamer, hermeneutika tidak bersifat reproduktif belaka, tapi juga produktif. Bagi dia, makna teks tidak harus makna bagi pengarangnya, melainkan makna bagi kita yang hidup di zaman ini. Maka dalam hal ini kerja hermeneutik adalah proses kreatif. ${ }^{19}$

\footnotetext{
${ }^{17}$ E. Sumaryono, Hermeneutik...hlm. 38-39.

${ }^{18}$ F. Budi Hardiman, "Hermeneutik: Apa Itu” hlm.9.

${ }^{19}$ Ibid., hlm. 10.
} 


\section{B. Tafsir dan Hermeneutika}

Dapatkah menafsirkan Al-Qur'an disebut sebagai kegiatan hermeneuein? Sekalipun tidak persis sama, tapi dengan ukuran tiga unsur utama hermeneuein yang sudah disebutkan di atas tafsir Al-Qur'an dapat dimasukkan dalam kategori kegiatan hermeneuein. Pertama, dari segi adanya pesan, berita yang seringkali berbentuk teks, tafsir Al-Qur'an jelas menafsirkan teks-teks yang terdapat dalam Kitab Suci Al-Qur'an; Kedua, harus ada kelompok penerima yang bertanya-tanya atau merasa asing terhadap pesan itu, dalam hal ini kaum Muslimin pembaca AlQur'an, baik yang berbahasa Arab apalagi yang tidak berbahasa Arab. Pesanpesan Al-Qur'an itu harus dijelaskan demikian rupa sehingga dapat dijadikan petunjuk dan pedoman kehidupan mereka; Ketiga, adanya pengantara yang dekat dengan kedua belah pihak. Untuk unsur ketiga ini pengantara yang paling dekat dengan sumber yaitu Allah SWT adalah Nabi Muhammad SAW, sehingga seluruh mufassir menjadikan Rasulullah SAW sebagai rujukan utama dalam menafsirkan pesan-pesan Allah. Sistem sanad diperlukan untuk menjaga otentitas dan validitas penjelasan Nabi tentang maksud Allah SWT.

Sedangkan masalah kedekatan para mufassir dengan pembaca, tentu saja hal itu tercapai pada saat penafsiran itu disampaikan kepada umat yang hidup sezaman dengan mereka. Semakin jauh pembaca tafsir dari mufassirnya semakin jauh pula jarak antara keduanya. Sehingga dalam kurun-kurun waktu kemudian sebagian dari penafsiran itu menjadi tidak relevan atau malah sudah kadaluwarsa. Di sinilah diperlukan mufassir-mufassir baru. Tapi tentu saja untuk hal-hal yang bersifat statis, substantif dan universal penjelasan mufassir klasik tetap relevan sepanjang zaman, yang terasa kadaluwarsa hanyalah aspek historisitas dari halhal yang bersifat substantif tersebut. Misalnya ilustrasi yang diberikan mufassir dalam menjelaskan tentang prinsip halalan thayyiban tidak akan selalu relevan dengan setiap zaman.

Dari segi teks yang ditafsirkan, seluruh mufassir tanpa kecuali meyakini bahwa teks suci Al-Qur'an berbeda dengan teks-teks lainnya, termasuk dengan teks hadits Nabi Muhammad SAW. Teks suci Al-Qur'an diyakini sepenuhnya berasal dari Allah SWT yang diwahyukan kepada Nabi Muhammad lewat 
Malaikat Jibril. Tidak ada intervensi manusia sedikitpun dalam pemilihan kata, penyusunan kalimat, apalagi dalam menentukan isi atau pesannya. Keterlibatan manusia, yaitu Rasulullah dan para sahabat hanyalah dalam menghimpun dan menjaga otentitas dan validitas periwayatannya. Dalam hal ini para mufassir menyepakati bahwa teks-teks kitab suci Al-Qur'an semuanya otentik dan valid secara mutawatir dengan sanad periwayatan bacaan yang jelas dan dipercaya. Untuk penulisan disepakati bahwa sistem penulisan Utsmani (ar-Rasmu al'Utsmâni) yang dijadikan acuan.

Sekalipun demikian, karena pesan Allah disampaikan dengan menggunakan bahasa yaitu bahasa Arab maka persoalannya sekarang tinggal bagaimana memahami pesan itu pertama dan utama sekali lewat pendekatan bahasa. Tentu saja sebuah bahasa tidak dapat terlepas dari latar belakang sosial budaya tempat, waktu dan pengguna bahasa itu sendiri. Dari sinilah para mufassir dengan intensitas yang berbeda-beda menjelaskan maksud Allah dengan firmanNya itu lewat penelitian bahasa baik dari tata bahasa (nahwu sharf), asal-usul kata (fiqh lughah), maupun sastranya (balâghah). Perbedaan penafsiran dapat saja terjadi karena perbedaan memahami makna kata yang digunakan. Contoh-contoh perbedaan itu dapat kita jumpai dalam kitab-kitab tafsir klasik, misalnya qurû' apakah berarti haidh atau suci, lâmasa (aw lâmastum an-nisâ') apakah hanya berarti menyentuh atau metafora untuk hubungan seksual, thâir (qâlu thâirukum ma'akum) apakah hanya berarti burung atau atau memuat sebuah konsep tertentu sesuai dengan tradisi Arab waktu itu? Perbedaan pemahaman dan kesimpulan hukum sangat mungkin terjadi disebabkan oleh perbedaan dalam memahami bahasa Al-Qur'an. Apalagi untuk istilah yang menganut konsep yang lebih abstrak seperti syura, keadilan, kepemimpinan dan lain sebagainya. Kitab-kitab tafsir bi ar-ra'yi lebih banyak melakukan pendekatan bahasa ini dibandingkan dengan tafsir bi al-ma'tsûr.

Selain pendekatan bahasa, yang tidak pernah dilupakan oleh para mufassir adalah melacak asbâb an-nuzûl atau latar belakang turunnya sebuah ayat. Penelitian asbâb an-nuẑ̂ul ini sama dengan penelitian terhadap hadits Nabi yaitu melalui kritik sanad dan matan untuk menilai riwayat mana yang valid dari Nabi 
atau laporan para sahabat tentang peristiwa yang melatar belakangi turunnya satu ayat atau kelompok ayat tertentu. Penilaian juga ditentukan oleh redaksi yang digunakan oleh perawi apakah tegas dan jelas menyatakan asbâb an-nuzûl atau hanya sekadar isyarat. Secara teknis perbedaan redaksi itu dapat dilihat dalam kitab-kitab 'Ulumul Al-Qur'an.

Teori Schleiermacher, pendekatan bahasa yang dilakukan para mufassir adalah upaya untuk melakukan rekonstruksi objektif-historis, sedangkan pendekatan latar belakang adalah dalam rangka rekonstruksi subyektif-historis. Dengan rekonstruksi pertama para mufassir bermaksud membahas sebuah pernyataan dalam hubungan dengan bahasa sebagai keseluruhan, dan dengan rekonstruksi kedua para mufassir membahas asal mulanya sebuah pernyataan masuk dalam ide wahyu yang difirmankan.

Mengacu kepada teori Schleiermacher tentang tugas hermeneutik, pertanyaan yang sangat penting adalah, dapatkah seorang mufassir memahami teks Al-Qur'an sebaik atau lebih baik daripada Allah (sebagai pengarang teks) sendiri, dan memahami Allah (sebagai pengarang teks) lebih baik daripada memahami dirinya sendiri? Tidak seorang pun mufassir yang mengatakan demikian. Bahkan sudah menjadi tradisi hampir semua mufassir untuk menutup uraiannya dengan pernyataan "Wallahu 'Alam bish-shawâb”. Begitu juga untuk yang kedua, jangankan untuk memahami Allah sebagai pengarang teks lebih baik dari daripada memahami dirinya sendiri, sedangkan untuk memahami diri sendiri (manusia) sering orang mengalami kesulitan. Apalagi bagi para mufassir, pengenalan tentang diri manusia juga didapat melalui teks-teks suci Al-Qur'an.

Terlihat dalam uraian teoritik di atas, bahwa para mufassir klasik sampai batas-batas tertentu telah melakukan kegiatan hermeneuein yang bersifat reproduktif. Tetapi bagaimana dengan hermeneutika yang bersifat produktif seperti yang diteorikan oleh Gedamer? Apakah para mufassir klasik juga sudah melakukannya? Sekadar mengingatkan, bagi Gadamer, hermeneutika tidak bersifat reproduktif belaka, tapi juga produktif. Bagi dia, makna teks tidak harus makna bagi pengarangnya, melainkan makna bagi kita yang hidup di zaman ini. Maka dalam hal ini kerja hermeneutik dalah proses kreatif. 
Jika dipahami dan diterapkan secara kaku, tentu saja tidak ada kitab-kitab tafsir yang dapat digolongkan kepada kerja produktif, karena perdefinisi saja sudah diberi batasan bahwa yang dimaksud tafsir adalah berusaha menangkap maksud Allah dalam firman-nya (bayân murâdillah) sebatas kemampuan manusia. Jadi bagaimana pun dalam definisi ini tafsir hanyalah bersifat reproduktif. Kreatifitas mufassir hanya dapat dilihat dalam mencari solusi problem kehidupan pada masa itu dari petunjuk atau pedoman yang terdapat dalam teks-teks Kitab Suci. Untuk hal ini semua kitabkitab tafsir ditulis memang untuk menjawab persoalan zamannya, walaupun tidak semua persoalan zaman itu harus baru sama sekali, karena sebagian juga dapat merupakan pengulangan persoalan-persoalan yang terjadi pada masa lalu. Demikianlah, dalam menafsirkan ayat-ayat tentang aqidah, ibadah dan ahwâl syakhshiyyah misalnya, para mufassir tidak lebih dari mengulang tafsir-tafsir terdahulu, apalagi menyangkut ayat-ayat tentang alam semesta, sejarah Nabi, Rasul dan umat pada masa yang lalu. Begitu juga tentang nilai-nilai moral yang bersifat universal dan berlaku sepanjang zaman.

Pendekatan hermeneutika ala Gadamer dapat ditemukan pada beberapa penafsiran kontemporer, paling kurang dalam metodologi yang ditawarkan, seperti yang ditawarkan oleh Fazlur Rahman dengan pendekatan historisnya di mana yang diperhatikan oleh mufassir tidaklah hanya konteks sosial tatkala ayat tersebut diturunkan, tapi juga perlu dihubungkan dengan konteks sosial kekinian. ${ }^{20}$ Bagi Rahman ada segitiga penafsiran, titik pertama ayat-ayat yang ditafsirkan, kedua, konteks tatkala ayat itu diturunkan, dan titik atau sudut ketiga konteks tatkala ayat itu ditafsirkan. Dalam perkembangannya banyak tawaran motodologi baru dalam menafsirkan Al-Qur'an oleh para pemikir Muslim kontemporer seperti Mohammed Arkoun, Nashir Hamid Abu Zaid, Muhammad Syahrur, Hassan Hanafi dan lain sebagainya-yang bukan porsi penulis untuk membahasnya.

\footnotetext{
${ }^{20}$ Fazlul Rahman, Metode dan Alternatif Neomodernisme Islam, terjemahan dan suntingan Taufik Adnan Amal (Bandung: Mizan, 1987), hlm. 55-56.
} 


\section{Studi Keislaman: Hermeneutika Fazlurrahman dan Mohammed Arkoun}

Secara substantif, kerja heremenutik sudah terdapat dalam tafsir Al-Qur'an sekalipun tidak dinamai dengan istilah hermeneutika. Bahkan kalau kita amati tawaran-tawaran metodologis dalam ulum at-tafsir jauh lebih kaya dari metode hermeneutika. Sebutlah pendekatan apa yang ditawarkan oleh hermeneutika sudah ada dalam pendekatan tafsir, mulai dari pendekatan bahasa, budaya, hukum dan lain sebagainya. Kitab-kitab tafsir yang ditulis oleh para ulama dahulu kaya dengan corak, terutama tafsir bi ar-ra'yi. Ada corak kalam, tasawuf, fiqh, bahasa dan sastra, ilmu pengetahuan dan lain sebagainya. Perbedaan yang paling substantif antara tafsir dan hermeneutik adalah pandangan terhadap nash. Dalam hermeneutika semua nash diperlakukan sama, sehingga tidak ada teks suci yang sakral dan tertutup. Tidak demikian halnya dengan tafsir, Al-Qur'an adalah nash suci yang sakral dan tertutup. Yang terbuka untuk dikiritik hanyalah penafsiran terhadap nash Al-Qur'an, bukan nash nya sendiri.

Sebagaimana yang di tulis oleh Nasr Hamid Al-Qur'an sebagai sebuah teks, pada dasarnya adalah produk budaya. (Tekstualitas Al-Qur'an, 2000) Hal ini dapat dibuktikan dengan rentang waktu terkumpulnya teks Al-Qur'an dalam 20 tahun lebih yang terbentuk dalam realitas sosial dan budaya. Oleh karena itu, perlu adanya dialektika yang terus-menerus antara teks (Al-Qur'an) dan kebudayaan manusia yang senantiasa berkembang secara pesat. Jika hal ini tidak dilakukan, maka teks Al-Qur'an akan hanya menjadi benda atau teks mati yang tidak berarti apa-apa dalam kancah fenomena kemanusiaan. Teks al-Qur'an masih sangat mungkin menjadi obat mujarab, bacaan shalat, atau perhiasaan bacaan yang dikumandangkan tiap waktu. Akan tetapi visi transformatif dan kemanusiaan AlQur'an akan bisa hilang begitu saja.

Mohammed Arkoun menegaskan, bahwa sebuah tradisi akan kering, mati, dan mandeg jika tidak dihidupkan secara terus- menerus melalui penafsiran ulang sejalan dengan dinamika sosial. (Rethinking Islam, 1999) Al-Qur'an sebagai teks yang telah melahirkan tradisi pemikiran, pergerakan, bahkan perilaku keagamaan yang sangat luas dalam rentang waktu panjang, tentu saja tidak bisa mengabaikan hal ini. 
Usaha menangkap dan mendapatkan pesan dari teks Allah berwujud dalam Al-Qur'an tentu saja mengandung problem. Karena, setiap usaha menerjemahkan, menafsirkan, atau mencari pemahaman terhadap teks klasik yang berjarak waktu, budaya, tempat sangat jauh dengan pembacanya, selalu digelayuti problem hermeneutika (penafsiran). Adanya problem penafsiran teks tersebut, maka ada sebuah teori filsafat yang digunakan menganalisis problem penafsiran, sehingga teks bisa dipahami secara benar dan komprehensif.

Hermeneutika sebagai sebuah metode interpretasi sangat relevan kita pakai dalam memahami pesan Al-Qur'an agar subtilitas inttelegendi (ketepatan pemahaman) dan subtilitas ecsplicandi (ketepatan penjabaran) dari pesan Allah bisa ditelusuri secara komprehensif. Maksudnya, pesan Allah yang diturunkan pada teks al-Qur'an melalui Nabi Muhammad itu tidak hanya kita pahami secara tekstual, juga bisa kita pahami secara kontekstual dan menyeluruh dengan tidak membatasi diri pada teks dan konteks ketika Al-Qur'an turun. Maka, teks AlQur'an beserta yang melingkupinya dapat digunakan agar selaras dan cocok dengan kondisi ruang, waktu, dan tempat di mana kita berada dan hidup.

Diskursus hermeneutika tidak bisa kita lepaskan dari bahasa, karena problem hermeneutika adalah problem bahasa. Karena itu, dalam memahami teks Al-Qur'an, disamping harus memahami kaidah tata bahasa, juga mengandaikan suasana psikologis dan sosio historis (wacana) yang teks tersebut. Istilah lain teknis yang diciptakan Ferdinand de Saussure di atas -seorang ahli bahasa dari Swiss adalah hubungan yang dialektis antara teks dan wacana. (K. Bertens, Filsafat Barat Abad XX, 1995). Sebuah penafsiran dan usaha pemahaman terhadap AlQur'an jika memakai metode hermeneutika, selalu terdapat tiga faktor yang senantiasa dipertimbangkan, yaitu dunia teks, dunia pengarang, dan dunia pembaca. Ketiga komponen itu memiliki konteks sendiri-sendiri, sehingga jika memahami teks Al-Qur'an hanya bertumpu pada satu dimensi tanpa mempertimbangkan dimensi yang lainnya, pemahaman yang diperoleh tidak akan luas dan miskin.

Tradisi hermeneutika, terutama metode yang diperkenalkan oleh Gadamer, akan terlihat jelas bahwa dalam setiap pemahaman teks, tidak terkecuali pada teks 
Al-Qur'an, unsur subyektivitas penafsir tidak mungkin disingkirkan. Bahkan secara ekstrem dikatakan bahwa sebuah teks akan berbunyi dan hidup ketika dipahami, diperhatikan, dan diajak berdialog oleh pembacanya. Dalam proses dialog, berarti pihak pembaca memiliki ruang kebebasan dan otonomi. Munculnya kitab tafsir Al-Qur'an yang berjilid-jilid yang masih dan akan terus berkembang menunjukkan bahwa pemahaman ulama' pada Al-Qur'an dan tradisi kenabian tidak pernah final. Dalam hermeneutika di kenal A Tripatite Hermeneutic, atau tiga proses hermeneutika yang meliputi, Exegesis, Interpretation dan Hermeneutic. Yang dimaksud tahap eksegesis ini mencoba memahami teks dimana ia lahir pada masanya, pada fase ini teks difahami pada makna original (lafadz teks), Inquired into the text, meaning in its original time and place, kedua, interpretation, explored the contemporary signicifance of the meaning (mengeksplore atau melacak kepentingan kontemporer dari arti itu, mencari makna lalu sesuai dengan kebutuhan sekarang), kemudian Hermeneutic, Formulated the rules and methods to get from exegesis to interpreration (memformulasikan aturan dan metode dari eksegesis ke interpretasi)

Mohammed Arkoun mungkin orang yang secara tuntas mencoba menggunakan hermeneutika dalam penafsiran Al-Qur'an. Untuk kepentingan analisisnya, Arkoun meminjam teori hermeneutika dari Paul Ricour, dengan memperkenalkan tiga level "perkataan Tuhan" atau tingkatan Wahyu. Pertama, wahyu sebagai firman Allah yang transenden, tak terbatas, yang tak diketahui oleh manusia, yaitu wahyu al-Lauh Mahfudz dan Umm al-Kitab. Kedua, wahyu yang nampak dalam proses sejarah. Berkenaan dengan Al-Qur'an, hal ini menunjuk pada realitas Firman Allah sebagaimana diturunkan dalam bahasa Arab kepada Nabi Muhammad selama kurang lebih dua puluh tahun. Ketiga, wahyu sebagaimana tertulis dalam Mushaf dengan huruf dan berbagai macam tanda yang ada di dalamnya. Ini menunjuk pada al-Mushaf al-Usmani yang dipakai orangorang Muslim hingga hari ini.

Ketiga tingkatan pemahaman wahyu di atas tentu saja memberikan implikasi pada penafsiran. Bagi Arkoun, dalam tafsir klasik atau modern, ketiga kategori wahyu itu tidak dibedakan sehingga menempatkan wahyu ketiga kategori di atas 
menjadi satu otoritas, yaitu skema otoritas Tuhan. Arkoun melihat secara kritis otoritas dari masing-masing teks Al Qur'an itu. Sehingga masing-masing tidak dicampuradukkan begitu saja. Dengan demikian, ia telah membongkar sesuatu di balik penyejarahan ketiga kategori otoritas tersebut. Hal ini menjadi teks Al Qur'an terbongkar dari selubung-selebung ideologis dan klaim kebenaran penafsiran yang sudah tidak relevan lagi.

Fazlur Rahman adalah salah seorang pemikir dan tokoh intelektual Islam kontemporer yang terkemuka. Tantangan kehidupan modern dan Kontemporer mengharuskan Fazlur Rahman untuk berfikir keras dalam menemukan deskripsi demi mengatasi masalah-masalah kehidupan yang muncul, menyadarkannya untuk mengkaji ulang beberapa pandangan yang baku di kalangan umat Islam, tetapi tidak akomodatif bahkan "sulit" diaplikasikan dalam kehidupan masyarakat. Fazlur Rahman memandang perlu diupayakan reinterpretasi Al Qur'an. Dalam hal ini, beliau menawarkan metode tafsir knotemporer yang berbeda dengan metodemetode era sebelumnya. Metode tafsir yang memiliki nuansa "unik" dan menarik untuk dikaji secara intensif, yaitu metode yang populer dengan nama "double movement" (Gerakan Ganda). Rahman menyiratkan pemahaman bahwa hermeneutika merupakan alat metodologis yang unggul. Ia pun mendalami teoriteori hermeneutika ketika sebagian besar pemikir Muslim lainnya belum mengenalnya. Karenanya, dalam blantika pemikiran Islam, ia dipandang sebagai tokoh yang turut merintis penerapan hermeneutika untuk mamahami teks Al Qur'an.

\section{Penerapan Hermeneutika Fazlurrahman}

Gagasan hermeneutika Al Qur'an Rahman merupakan suatu tawaran yang menarik, ketika kita mencoba mencermati dan mengaitkannya dengan persoalan kontemporer. Sebagai contohnya adalah ayat yang membicarakan tentang poligami. $^{21}$ Langkah awal, Rahman mencoba memahami makna poligami dalam Al Qur'an dengan menelaah bagaimana al-Qur'am merespon realitas poligami pada saat itu. Kemudian, respon Al Qur'an di generalisir dan dinyatakan sebagai pernyataan yang

\footnotetext{
${ }^{21}$ Kurdi dkk, Hermeneutika Al-Qur'an dan Hadis, hlm 79
} 
mempunyai tujuan-tujuan moral sosial yang umum (prinsip-prinsip umum, nilai-nilai dan tujuan jangka panjang) yang dapat "disaring" dari ayat-ayat spesifik yang berkaitan dengan latar belakang sosio-historis dan ratio legis yang sering diungkapkan. Dari prinsip-prinsip umum tersebut kita bawa pada era sekarang, kita analisa persamaan dan perbedaannya untuk dapat diformulasikan hukum yang tepat dan mampu menjawab hingar bingar poligami yang menimbulkan polemik pro dan kontra. $^{22}$

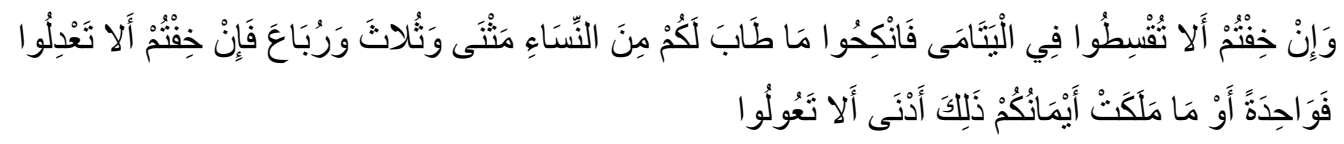

Ayat tersebut turun sebagai respon terhadap perilaku para wali dari anak yatim, baik laki-laki ataupun perempuan yang sering menyelewengkan harta kekayaan mereka. Kemudian Al Qur'an menyerukan agar mereka (para wali) tidak menyelewengkan harta kekayaan itu, dan mereka boleh mengawini (perempuan yatim) sampai empat orang diantara mereka, asalkan mereka dapat berlaku adil. Seruan ini juga didukung oleh Q.S al-Nisa' (4): 127. Pernyataan diatas dengan melihat asbab al-nuzul-nya menunjukkan bahwa masalah ini muncul dalam konteks perempuan-perempuan yatim. Tapi kemudian al-Qur'an juga mengatakan: "Betapapun kalian menginginkannya, namun kalian tidak akan dapat berlaku adil kepada perempuan-perempuan tersebut" (4:129). ${ }^{23}$ Tampaknya ada sebuah kontradiksi di antara izin untuk beristri sampai empat orang (aspek legal) dan keharusan untuk berlaku adil kepada mereka (ajaran moral Al Qur'an) itu dengan pernyataan tegas bahwa keadilan terhadap isteri-isteri tersebut adalah mustahil. ${ }^{24}$

Tampaknya memang benar bahwa izin berpoligami itu adalah taraf legal atau hukum, sementara sanksi-sanksi yang diberikan kepadanya pada hakekatnya adalah ideal moral yang harus diperjuangkan masyarakat sebuah cita-cita moral yang mana masyarakat diharapkan bergerak kearahnya, karena poligami itu tidak dapat dihilangkan dengan begitu saja.

\footnotetext{
${ }^{22}$ Loc. Cit. Hlm 80

${ }^{23}$ Ibid

${ }^{24}$ Fazlur Rahman, Major Themes Of The Qur'an terj., hlm 70
} 


\section{Kesimpulan}

Penggunaan istilah Hermeneutika dalam kajian interpretasi pada dunia Islam adalah sesuatu yang baru. Sejak Hasan Hanafi memperkenalkan Hermeneutika pada dunia pemikiran Islam dalam bukunya yang berjudul: “Les Methodes d'Exeges, Essai sur La Science des Fordements de la Comprehesion, Ilm Usul al-Fiqh” pada tahun 1965. Dan dalam bukunya yang lain berjudul: "Islam in the Modern World, Religion, Ideologi, and Development", vol: I, terutama pada subbab berjudul: "Method of the mistic Interpretation", dan pada vol: II pada subbab: "Hermeneutics Libration and Revolution”.Maka dikalangan Ulama' Islam terbagi menjadi dua kelompok yaitu kelompok yang menerima hermeneutika dalam pemikiran Islam dan kelompok yang menolak hermeneutika.

Alasan kelompok yang menerima hermeneutika dalam pemikiran Islam adalah sebagai berikut:

1. Al Qur'an adalah teks-teks manusia biasa (hasil dari kebudayaan) dan karena itu perlu adanya interpretasi agar dapat di fahami.

2. Al Qur'an kini sudah saatnya ditafsirkan ulang, karena tafsir Al Qur'an yang ada sekarang hanya ditafsirkan secara tekstual, maka perlu adanya penyesuaian dengan kondisi (konteks) masa sekarang.

3. Penafsiran Al-Qur'an yang ada ini masih relatif kebenaranya. Sehingga masih memungkin penafsiran-penafsiran yang lebih bebas dari itu.

4. Unsur pokok yang menjadi pilar utama Hermeneutika: text, author, dan audience, tidak berbeda dengan konsep tafsir Al-Qur'an. yaitu; 1) siapa yang mengatakan, 2) kepada siapa diturunkan, dan 3) ditujukan kepada siapa

5. Praktek hermeneutika telah dilakukan dalam dunia penafsiran Islam sejak lama, bahkan sejak awal kajian tafsir, khususnya ketika menghadapi AlQur'an. Bukti dari hal itu adalah: 1) kajian-kajian mengenai asbab al-nuzul dan nasikh-mansukh, 2) penggunaan berbagai teori dan metode dalam proses penafsiran, dan 3) adanya kategorisasi tafsir tradisional, seperti; tafsir syi'ah, 
tafsir mu'tazilah, tafsir hukum, tafsir filsafat dan yang lain. Ini menunjukkan kesadaran tentang kelompok, ideologi, priode, maupun horizon social tertentu

6. Istilah hermeneutika dalam pengertiannya hampir sama dengan istilah tafsir atau ta'wil. yang berarti menerangkan atau mengungkap (al-bayan wa alkashf), sedangkan hermeneutika memiliki pengertian interpretasi.

7. Ada kesejajaran antara semangat Reformasi Protestan dan Gerakan Salafiyah dalam Islam. Dalam gerakan Salafiyah, dikembangkan suatu tradisi penafsiran Qur'an yang kurang lebih independen dari tradisi mazhab. Inilah yang menjelaskan kenapa dalam keputusan-keputusan majlis tarjih Muhammadiyah, misalnya, rujukan kepada Kitab Kuning yang memuat khazanah tradisi bermazhab sama sekali kurang, atau malah tak ada sama sekali.

Sedangkan kelompok yang menolak hermeneutika dalam kajian Islam, memiliki alasan sebagai berikut:

1. Hermeneutika berlandaskan pada pedoman bahwa segala penafsiran AlQur'an itu relatif. Padahal, fakta menunjukkan bahwa para mufassir sepanjang masa tetap memiliki pedoman-pedoman pokok dalam menafsirkan Al-Qur'an.

2. Para hermeneut berpendapat bahwa penafsir bisa lebih mengerti lebih baik daripada pengarang, mustahil dapat terjadi dalam Al-Qur'an. Tidak pernah ada seorang mufassir Al-Qur'an yang mengklaim bahwa dia lebih mengerti dari pencipta atau pengarang Al-Qur'an, yaitu Allah SWT.

3. Konsep hermeneutika yang berpedoman bahwa interpretasi teks yang berdasarkan doktrin dan bacaan yang dogmatis harus ditinggalkan dan dihilangkan (deabsolutisasi) juga tidak sesuai dengan ajaran Islam. Sebagai umat Islam, kita harus meyakini bahwa Al-Qur'an adalah sebuah mukjizat dan berbeda dengan teks-teks biasa. Doktrin kebenaran Al-Qur'an semuanya bersumber kepada Allah dan menjadi syarat keimanan umat Islam.

4. Hermeneut yang mengatakan bahwa pengarang tidak mempunyai otoritas atas makna teks, tapi sejarah yang menentukan maknanya juga tidak mungkin diaplikasikan pada Al-Qur'an. Seluruh umat Islam sepakat bahwa otoritas kebenaran Al-Qur'an tetap dipegang oleh Allah SWT sebagai penciptanya. 
Realitas juga menunjukkan bahwa Allah melalui Al-Qur'an justru mengubah sejarah, bukan dipengaruhi atau ditentukan oleh sejarah. Diantara pengaruh Al-Qur'an adalah fakta bahwa Al-Qur'an telah melahirkan sebuah peradaban baru yang disebut sebagai "peradaban teks" (hadarah al-nash).

5. Tradisi hermeneutika dalam Bible memang memungkinkan. Terdapat berbagai macam Bible dan tiap-tiap Bible ada pengarangnya. Tapi teks Al-Qur'an pengarang adalah hanya Allah. Karena itu metode hermeneutika yang diaplikasikan pada Bible tidak mungkin digunakan dalam Al-Qur'an.

6. Bible diliputi serangkaian mitos dan dogma yang menyesatkan. Hal tersebut yang memicu digunakannya hermeneutika terhadap Bible. Sedangkan AlQur'an itu pasti dan terjaga status keasliannya. Begitu pula sejarah dan tradisi tafsir Al-Quran. Karena Al-Qur'an diciptakan oleh Dzat yang maha sempurna dan ditafsirkan oleh makhluk yang penuh keterbatasan, maka tidak akan pernah ada kata sempurna tentang penafsirannya.

7. Orang yang ingin menafsirkan al-Quran harus memenuhi beberapa ketentuan seperti: menguasai as-Sunnah, yang dalam hal ini adalah memahami sepenuhnya nash (teks) as-Sunnah, mengetahui dan memahami kisah-kisah sejarah di dalam Al-Qur'an atau berita tentang berbagai umat manusia pada zaman dulu yang bersumber dari Rasulullah. Menguasai ilmu Tauhid, ilmu Fiqih, ilmu I'rab (gramatika), ilmu Balaghah, ilmu sejarah dan lain sebagainya. Hal ini tidak berlaku untuk hemeneutik. 


\section{Daftar Pustaka}

Ahmad Warsun Munawwir, Kamus al-Munawwir, Arab-Indonesia Yogyakarta: Pondok Pesantren al-Munawwir, 1984.

Al-Imam As-Suyuthi, Ilmu Tafsir (terjemahan) Surabaya : Bina Ilmu, 1982

E. Sumaryono, Hermeneutik Sebuah Metode Filsafat, Yogyakarta: Kanisisus, 1993

Fakhruddin Faiz, Hermeneutika Qur'ani, Yogyakarta: Qalam, 2002

FX. Mudji Sutrisno dan F. Budi Hardiman (ed), Para Filsuf Penentu Gerak Zaman, Yogyakarta: Kanisius, 1994.

FX. Budi Hardiman, "Hermeneutik itu Apa?”, dalam Majalah Basis, no. 40, th. 1991

Fazlur Rahman, Metode dan Alternatif Neomodernisme Islam, tejemahan dan suntingan Taufik Adnan Amal, Bandung: Mizan, 1987.

Islah Gusmian, Khazanah Tafsir Indonesia; dari Hermeneutika hingga Ideologi, Jakarta:Teraju, 2002

Islamia, Hermeneutika Versus Tafsir Al-Quran, Majalah Pemikiran dan Peradaban Islam, Thn. 1, No. 1, Jakarta: Khairul Bayan,

Jalâl ad-Dîn 'Abd ar-Rahmân as-Suyûthi, al-Itqân fî̀ 'Ulûm Al-Qur'an Beirut: Dar alFikr, t.t.

Komaruddin Hidayat, Memahami bahasa Agama: Sebuah Kajian Hermeneutik, Jakarta: Yayasan Wakaf Paramadina, 1996

Mannâ' al-Qaththâan, Mabâhits fî 'Ulûm Al-Qur'an Riyâdh: Muassasah ar-Risâlah, 1976.

Muhammad Shahrur, Prinsip dan Dasar Hermeneutika Al-Quran Kontemporer, Yogyakarta: El Saq, 2004

Mudjia Raharjo, Hermeneutika Gadamerian, UIN-Malang Press, Malang, 2007,

Muhammad Husain adz-Dzahabi, At-Tafsîr wa al-Mufassirûn Kairo: Dar al-Kutub alHadîtsah, 1976.

Syamsuddin Arif, Orientalis \& Diabolisme Pemikiran-Bab Hermenutika dan Tafsir Al-Qur'an, Jakarta : Gema Insani Press, 2008.

Yunahar Ilyas, Feminisme dalam Kajian Tafsir Al-Qur'an Klasik dan Kontemporer, Yogyakarta: Pustaka Pelajar, 1997. 
